\title{
Pengaruh Jumlah Pengunjung, Ulasan Produk, Reputasi Toko Dan Status Gold Badge pada Penjualan Dalam Tokopedia
}

\author{
Mochammad Nurul ${ }^{1}$ \\ Fakultas Ekonomi dan Bisnis \\ Universitas Airlangga, Indonesia \\ e-mail: mocha.nurul@gmail.com
}

\author{
Noorlailie Soewarno ${ }^{2}$ \\ Fakultas Ekonomi dan Bisnis \\ Universitas Airlangga, Indonesia
}

\author{
Isnalita $^{3}$ \\ Fakultas Ekonomi dan Bisnis \\ Universitas Airlangga, Indonesia
}

\begin{abstract}
ABSTRAK
Penelitian ini bertujuan untuk mengetahui bagaimana beberapa item pada halaman produk tokopedia (jumlah pengunjung produk, ulasan pelanggan, reputasi toko, dan gold badge) dapat mempengaruhi tingkat penjualan. Penelitian ini menganut desain penelitian kuantitatif dan jenis penelitian deskriptif dengan kategori korelasi. Data dikumpulkan dan diuji dengan metode analisis regresi berganda menggunakan aplikasi SPSS versi 21. Data diperoleh dari 120 produk buku di Tokopedia meliputi data penjualan, jumlah pengunjung, ulasan produk, reputasi toko, dan status gold merchant. Hasil penelitian menunjukkan bahwa ulasan produk merupakan variabel yang paling penting daripada variabel lain seperti jumlah pengunjung, reputasi, dan gold merchant.
\end{abstract}

Kata Kunci : $\quad$ C2C, Marketplace, Online, Penjualan, Tokopedia.

\section{Influence Of Popularity, Product Review, Store Reputation And Gold badge Status On Sales In Tokopedia}

ABSTRACT

This study aims to find out the influence of some items in Tokopedia's product pages (product popularity, customer reviews, store reputation, and gold badges) toward sales. We were using quantitative as the research design, descriptive research analysis and correlation category. We collect data and tested it using the multiple regression analysis method with SPSS version 21. The results show that product review is the most important variable than other variables such as popularity, reputation, and gold merchants.

Keywords: $\quad$ C2C, Marketplace, Online, Sales, Tokopedia.

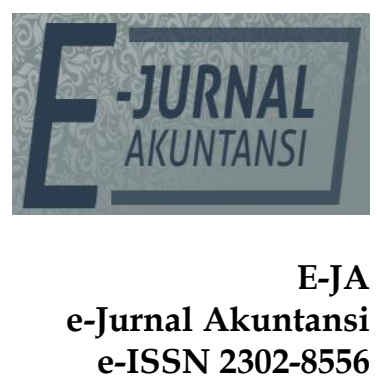

Vol. 28 No. 3

September 2019

Hal. 1855-1865

Artikel masuk:

05 Juli 2019

Tanggal diterima: 04 September 2019 


\section{PENDAHULUAN}

Budaya berbelanja mengalami perubahan dari waktu ke waktu. Awal mula masyarakat harus ke pasar untuk membeli barang, kemudian berkembang menjadi pasar swalayan, dan perkembangan terakhir adalah munculnya marketplace. Masyarakat yang ingin berbelanja di marketplace tidak perlu ke luar dari rumah untuk pergi ke toko, mereka cukup membuka aplikasi dan website dari perangkat yang memiliki sambungan internet. Dalam pasar terdapat dua subyek utama yaitu pembeli dan penjual. Pembeli berusaha untuk memenuhi kebutuhannya baik berupa barang ataupun jasa sedangkan penjual berusaha untuk memenuhi kebutuhan pembeli. Penjual senantiasa melakukan inovasi untuk mengetahui kebutuhan pembeli. Teori perilaku konsumen digunakan untuk memahami faktor-faktor yang mempengaruhi pembeli dalam memilih barang. Walters (1974) mendefinisikan perilaku konsumen sebagai proses di mana individu memutuskan pembelian berdasarkan apa, kapan, dimana, bagaimana, dan dari siapa ia membeli barang dan jasa.

Penelitian mengenai marketplace $\mathrm{C} 2 \mathrm{C}$ (consumer to consumer) penting untuk dikembangkan karena perkembangannya seiring dengan perkembangan teknologi yang sangat pesat $(\mathrm{Ou}, 2011)$. Penyedia jasa marketplace seperti amazon.com menganalisis data interaksi pelanggan termasuk pembelian, penilaian, dan pola pencarian sebelumnya, serta informasi demografi dengan tujuan untuk mengetahui interaksi para pelanggan (Grange \& Benbasat, 2010). Dari kegiatan tersebut kemudian mereka menciptakan sistem rekomendasi berupa iklan berbayar yang mampu meningkatkan penjualan. Banyak penelitian yang telah membahas hubungan fitur iklan berbayar (sistem rekomendasi) dengan tingkat penjualan. Penelitian ini menggunakan variabel selain fitur iklan berbayar seperti jumlah pengunjung, ulasan produk, reputasi toko dan status gold badge yang terdapat pada halaman penjualan situs marketplace Tokopedia.

Keunggulan marketplace bagi pelanggan adalah adanya fasilitas interaksi antar pelanggan untuk menambah pengetahuan dalam berbelanja melalui fitur ulasan. Penggunaan ulasan memungkinkan pembeli untuk memberikan umpan balik produk berupa ulasan dan memberi peringkat pada halaman produk (Pathak, 2014). Ulasan dari pelanggan lain dapat dijadikan sebagai bahan pertimbangan untuk pengambilan keputusan membeli produk. Umpan balik yang baik dari pelanggan dapat meningkatkan kepercayaan pelanggan lain terhadap kualitas barang yang dijual.

Penyedia jasa layanan digital marketplace memberikan layanan tambahan untuk para penjual untuk meningkatkan kepercayaan pelanggan atas produk yang dijual (Alba et al., 1997). Tokopedia memberikan layanan serupa dinamai "Gold Badge". Penjual yang menggunakan fitur "gold badge" mendapatkan beberapa keuntungan tambahan berupa penampilan toko dan display produk yang lebih bagus serta terlihat lebih profesional dimata pembeli. Terlebih lagi simbol ini akan tercantum pada setiap produk yang dijual dan disamping nama toko.

Tokopedia merupakan salah satu situs marketplace C2C (consumer to consumer) yang terkenal di era industri 4.0. Situs ini menjadi tempat bertemunya penjual dan pembeli untuk melakukan transaksi produk tanpa dipungut biaya tambahan. Selain bebas biaya, situs ini menggunakan sistem rekening bersama 
sehingga baik pembeli maupun penjual merasa aman dalam melakukan transaksi. CEO Tokopedia, William Tanuwijaya menngungkapkan bahwa lebih dari satu juta masyarakat Indonesia merintis usaha perdagangan di situs Tokopedia (Luciana, 2017).

Beberapa penelitian sebelumnya juga ikut andil dalam ide penelitian ini. Hasil penelitian Pathak (2014) menunjukkan bahwa sistem rekomendasi 'sales' berhubungan positif dengan tingkat penjualan produk buku di amazon. Penelitian yang sama juga dilakukan oleh (Schafer et al., 2001) dengan hasil bahwa Sistem rekomendasi E-Commerce dapat meningkatkan penjualan melalui personalisasi kebutuhan tiap-tiap pelanggan. Selain itu penelitian yang dilakukan oleh (Mahadevan \& Series, 2000) menunjukkan bahwa E-Commerce sangat diminati oleh masyarakat karena praktis dan mudah untuk diaplikasikan. Penelitian terakhir dari (Adomavicius \& Tuzhilin, 2005) menunjukkan bahwa terdapat tiga jenis Sistem rekomendasi dalam E-Commerce, diantaranya content based, collaborative, dan hybrid recommendation approach. Penelitian Zheng \& Jin (2016) menunjukkan bahwa reputasi penjual dalam E-Commerce dapat mempengaruhi keputusan pembeli untuk memilih produk. Diantara penelitian yang saya sebutkan, masih banyak penelitian lain yang membahas mengenai $E$ Commerce.

Penelitian ini bermaksud untuk menganalisis dampak dan efektivitasnya dari perspektif penjualan barang. Untuk mengevaluasi tingkat efektivitasnya, kami menganalisis efeknya pada parameter bisnis utama yaitu penjualan. Selain itu variabel pengukuran kami tidak hanya menggunakan fitur gold merchant saja, tetapi juga termasuk ulasan pelanggan, viewer produk tersebut, nilai poin toko yang tercantum dalam halaman penjual. Kami menggunakan buku sebagai kategori produk dan menganalisis data penjualan dan rekomendasi dari pengecer online populer tokopedia untuk mempelajari dampak fitur sistem tambahan pada penjualan.

Consumer decision model yang juga dikenal dengan sebutan Engel-BlackwellMiniard Model pertama kali dikembangkan pada tahun 1968 oleh Engel, Kollat, dan Blackwell, secara terus menerus direvisi (Creyer, 1997). Model dibentuk dari enam poin proses pengambilan keputusan: munculnya kebutuhan, diikuti dengan pencarian informasi, baik secara internal maupun eksternal, evaluasi alternatif, pembelian, konsumsi, dan evaluasi pasca pembelian. Keputusan pembelian ini dipengaruhi oleh tiga faktor utama, pertama stimuli yang diperoleh dari upaya pemasaran. Kedua, variabel lingkungan eksternal yang terdiri atas jumlah viewer product, ulasan product, reputation product.

Perkembangan teknologi memungkinkan para konsument untuk memberikan ulasan dan rekomendasi secara online. Hal ini dapat membantu konsumen lainnya untuk memastikan kualitas barang sebelum membuat keputusan pembelian. Dunia digital menyediakan platform yang ideal bagi konsumen untuk mencari dan berbagi informasi tentang kualitas produk dalam berbagai bentuk digital dari mulut ke mulut, seperti peringkat dan ulasan produk online, situs jejaring sosial, blog, dan sebagainya (Dellarocas, 2003). Kata digital dari mulut ke mulut dapat mempengaruhi keputusan pembelian ketika konsumen ragu dari segi kualitas produk. Evaluasi tersebut dapat terjadi sebelum atau sesudah pembelian. 
Dengan adanya ulasan digital, kualitas barang yang dibeli dapat dinilai dengan mudah. Ketika membuat keputusan pembelian untuk barang yang belum memiliki ulasan dari konsumen lain, konsumen biasanya beralih ke berbagai sumber informasi kualitas pada produk (Nelson, 1970). Studi empiris menunjukkan bahwa permintaan informasi produk dari berbagai sumber sangat tinggi. Salah satu informasi tersebut adalah mengenai harga, di mana harga tinggi berfungsi sebagai sinyal bahwa barang tersebut sering memiliki banyak peminat (Caves \& Greene, 1996), iklan sebagai sumber informasi barang yang dicari (Nelson, 1974), dan ulasan dari para pelanggan lain memiliki pengaruh substansial pada permintaan barang (Eliashberg \& Shugan, 1997; Reinstein \& Snyder, 2005). Penelitian sebelumnya telah menunjukkan bahwa digital-word dari internet juga memiliki efek signifikan pada pembelian konsumen. Chevalier dan Mayzlin (2006) menemukan bahwa perbedaan jumlah ulasan yang diterima dua pedagang online berhubungan positif dengan perbedaan dalam tingkat penjualan buku pada masing-masing toko.

Jumlah viewer diukur dengan seberapa banyaknya orang yang melihat produk tersebut di toko online (Pathak, 2014). Semakin banyak jumlah viewer maka semakin dikenalnya produk tersebut di mata masyarakat (Ansari, Essegaier, \& Kohli, 2000). Berdasarkan argumen tersebut maka dapat disimpulkan bahwa semakin banyak jumlah viewer maka semakin besar juga jumlah penjualan akan product tersebut. Hal ini dikarenakan produk tersebut terkenal di masyarakat dan banyak masyarakat yang mencari produk tersebut (Palmer, 2002).

$\mathrm{H}_{1}$ : Jumlah viewer berpengaruh positif terhadap penjualan barang.

Ulasan produk merupakan ulasan yang diberikan oleh pelanggan pada produk tersebut (Spink, 2002). Ulasan tersebut biasanya berisikan komentar tentang bagus atau tidaknya suatu produk yang dibuat oleh customer yang telah membeli produk tersebut. Semakin banyak ulasan yang baik, akan dapat menarik perhatian pelanggan untuk membeli produk tersebut.

$\mathrm{H}_{2}$ : Ulasan produk berpengaruh positif terhadap penjualan barang.

Reputation mengukur tingkat seberapa baik penjual dalam melayani pembeli hal ini dapat dilihat dari jumlah skor yang berupa bintang yang terdapat dalam profil penjual (Keeney, 1999). Semakin banyak jumlah bintang yang dimiliki penjual, maka semakin baik pula reputasi yang dimiliki penjual. (Adomavicius \& Tuzhilin, 2005) mengatakan bahwa semakin baik reputasi sebuah toko online, maka semakin banyak pula penjualan yang dilakukan oleh toko tersebut.

$\mathrm{H}_{3}$ : Reputation berpengaruh positif terhadap penjualan barang.

Gold merchant merupakan fitur berbayar yang dapat memberikan kemudahan bagi penjual dalam mengelola toko online. Pedagang online Tokopedia tidak diwajibkan untuk menjadi anggota gold merchant sehingga mereka tetap dapat berjualan meskipun dengan akun gratis. Bagi penjual yang ingin mendapatkan lebih banyak konsumen, mereka sangat disarankan untuk berlangganan fitur tersebut. Dengan berlangganan Gold merchant, penjual dapat menikmati beragam fasilitas unggulan yang ada di Tokopedia seperti Statistik Toko, Pemberian Cashback, Cover Toko, Gold Ticket, Bonus Saldo 'TopAds', dan 
masih banyak lagi. Penjual juga berkesempatan mendapatkan Gold badge jika nilai performa toko mencapai 75 .

$\mathrm{H}_{4}$ : Gold merchant berpengaruh positif terhadap penjualan barang.

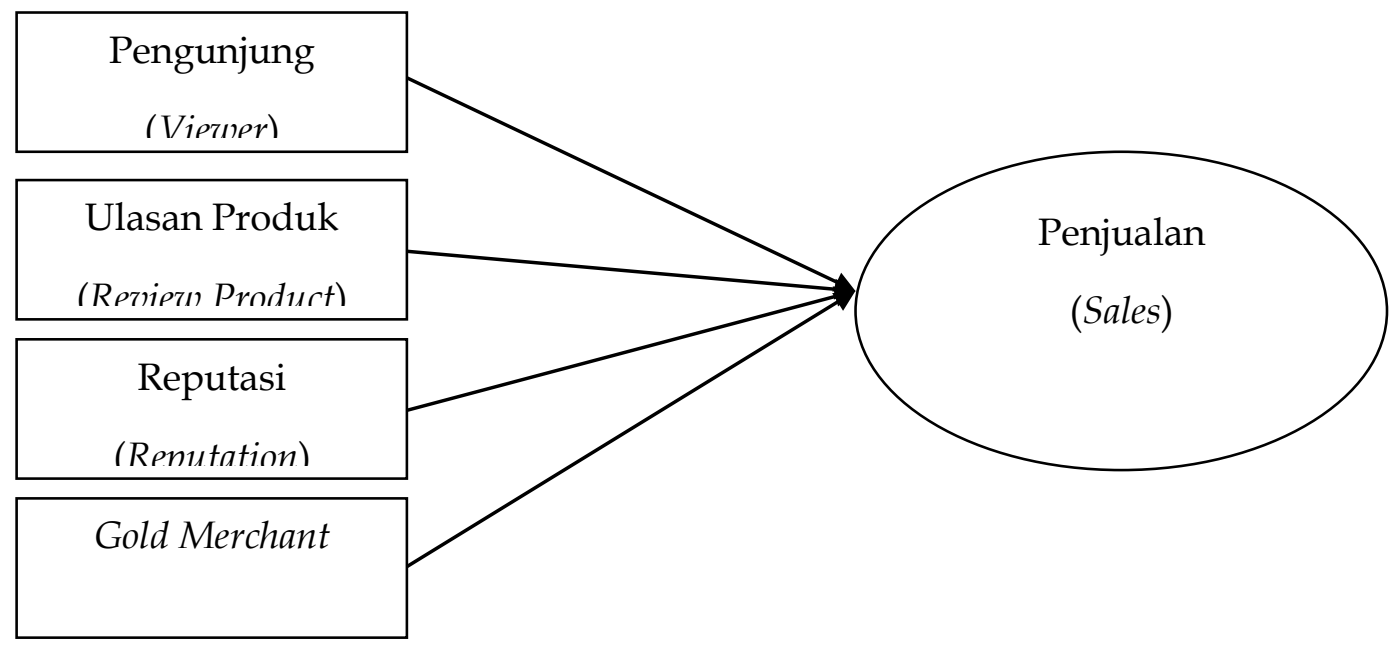

Gambar 1. Model Penelitian

Sumber : Data Penelitian, 2019

\section{METODE PENELITIAN}

Metode yang digunakan menggunakan desain penelitian kuantitatif dan jenis penelitian deskriptif dengan kategori korelasi. Penelitian kuantitatif menggunakan banyak data berupa angka, dimulai dari pengumpulan data, tafsiran data, juga tampilan hasilnya (Arikunto, 2010). Metode deskriptif memiliki tujuan menggambarkan sifat sesuatu yang muncul pada saat penelitian dilakukan dan mengetahui penyebab dari suatu gejala tertentu (Abdullah, 2015). Pendekatan korelasi dalam penelitian deskriptif adalah penelitian yang dirancang untuk menentukan hubungan variabel-variabel yang berbeda dalam suatu populasi. Dengan pendekatan korelasi peneliti dapat mengetahui besaran kontribusi variabel-variabel bebas terhadap variabel terikat serta besarnya arah hubungan yang terjadi.

Penelitian ini menggunakan populasi pedagang online pada marketplace Tokopedia dengan sampel kategori jenis produk buku. Data didapatkan dari rekomendasi produk yang ditampilkan pada website tokopedia dengan kategori produk yang dijual berupa buku. Sampel yang didapat sebanyak 120 dengan lima kategori diantaranya jumlah barang terjual, jumlah viewers, jumlah ulasan, jumlah reputasi, dan status gold merchant. Jumlah barang terjual, ulasan, dan reputasi diukur dengan skala ordinal. Status gold merchant diukur dengan variabel dummy.

Teknik analisis data menggunakan regresi berganda dengan aplikasi SPSS versi 21. Variabel dependen penelitian ini adalah Tingkat penjualan yang didapat dari halaman produk. Variabel independen diantaranya pengunjung (viewer), ulasan produk (review product), reputasi (reputation), dan status 'gold badge' yang didapat dari halaman produk. 
Tabel 1. Definisi Operasional

\begin{tabular}{|c|c|}
\hline Variabel & Definisi Operasional \\
\hline $\begin{array}{l}\text { Penjualan } \\
\text { (Sales) }\end{array}$ & $\begin{array}{l}\text { Penjualan didapatkan dari halaman produk. Variabel ini } \\
\text { menentukan seberapa banyak jumlah produk tersebut terjual kepada } \\
\text { pelanggan. }\end{array}$ \\
\hline $\begin{array}{l}\text { Pengunjung } \\
\text { (Viewer) }\end{array}$ & $\begin{array}{l}\text { Jumlah pengunjung didapatkan dari halaman produk. Variabel ini } \\
\text { menentukan seberapa sering produk tersebut dilihat oleh pelanggan. }\end{array}$ \\
\hline $\begin{array}{l}\text { Ulasan Produk } \\
\text { (Review } \\
\text { Product) }\end{array}$ & $\begin{array}{l}\text { Ulasan produk didapatkan dari halaman produk. Variabel ini } \\
\text { menentukan jumlah pelanggan yang memberikan ulasan setelah } \\
\text { menerima produk tersebut. }\end{array}$ \\
\hline Reputasi & $\begin{array}{l}\text { Reputasi toko didapatkan dari halaman produk. Variabel ini } \\
\text { menentukan seberapa cepat respon toko terhadap pembeli. }\end{array}$ \\
\hline $\begin{array}{l}\text { Status Gold } \\
\text { merchant }\end{array}$ & $\begin{array}{l}\text { Status gold merchant didapatkan dari halaman produk. Variabel ini } \\
\text { menentukan apakah toko menggunakan fitur tambahan berbayar } \\
\text { atau tidak dalam menjual produknya. }\end{array}$ \\
\hline
\end{tabular}

\section{HASIL DAN PEMBAHASAN}

Tahap pertama yang dilakukan adalah pengujian normalitas untuk menentukan apakah data yang diambil terdistribusi normal atau tidak. Hasil pengujian menunjukkan bahwa data yang dikumpulkan terdistribusi normal. Hasil tersebut terlihat dari sebaran data yang bergerak hampir lurus mengikuti garis.

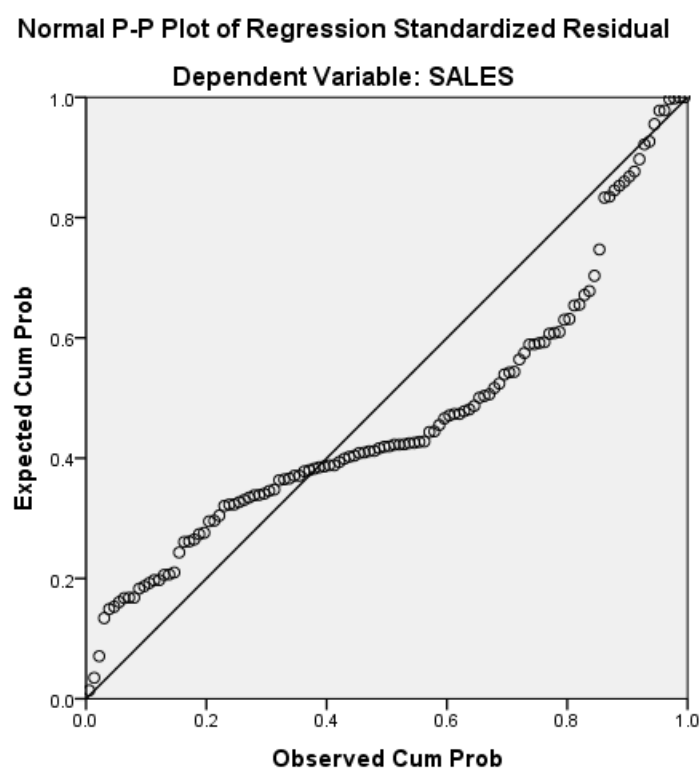

Sumber : Data Penelitian, 2019

\section{Gambar 2. Hasil Uji Normalitas}


Tahap kedua yang dilakukan adalah melakukan uji ANOVA untuk menentukan apakah research model yang digunakan layak uji. Tingkat signifikansi yang digunakan sebesar 0,05. Hasil uji ANOVA menunjukkan model yang digunakan layak untuk diuji dilihat dari tingkat signifikansi 0.000 .

Tabel 2. Hasil uji ANOVAa

\begin{tabular}{lllllll}
\hline \multirow{2}{*}{ Model } & & $\begin{array}{l}\text { Sum of } \\
\text { Squares }\end{array}$ & df & $\begin{array}{l}\text { Mean } \\
\text { Square }\end{array}$ & $F$ & Sig. \\
\hline \multirow{3}{*}{1} & Regression & 596.796 .504 & 4 & 149.199 .126 & 40.411 & $.000^{\mathrm{b}}$ \\
& Residual & 424.585 .088 & 115 & 3.692 .044 & & \\
& Total & 1.021 .381 .592 & 119 & & & \\
\hline
\end{tabular}

Sumber : Data Penelitian, 2019

Tahap ketiga adalah pengujian Multikolinearitas. Uji ini dimaksudkan untuk mengidentifikasi adanya autokorelasi antar variabel yang diuji. Penggunaan model durbin watson memiliki rentang 1,753 $>n<2,246$. Nilai hasil uji masuk dalam rentang ' $n$ ' sebesar 1,785 sehingga data yang dipakai tidak mengalami autokorelasi.

Tabel 3. Hasil Uji Multikolinearitas (Durbin Watson)

\begin{tabular}{cccccc}
\hline Model & $\mathrm{R}$ & $R$ Square & $\begin{array}{c}\text { Adjusted } R \\
\text { Square }\end{array}$ & $\begin{array}{c}\text { Std. Error of Durbin-Watson } \\
\text { the Estimate }\end{array}$ & \\
\hline 1 & $.764^{\mathrm{a}}$ & .584 & .570 & 60.76219 & 1.785 \\
\hline
\end{tabular}

Sumber : Data Penelitian, 2019

Tahap keempat melakukan uji regresi berganda untuk mengetahui tingkat signifikansi masing-masing variabel independen terhadap penjualan. Uji regresi berganda digunakan karena data penelitian terdistribusi normal dan bersifat independen. Tingkat signifikansi yang digunakan sebesar 0,05 atau 5\%.

Tabel 4. Hasil Uji Regresi Berganda

\begin{tabular}{lccccc}
\hline \multirow{2}{*}{ Model } & \multicolumn{2}{c}{ Unstandardized Coefficients } & $\begin{array}{l}\text { Standardized } \\
\text { Coefficients }\end{array}$ & $\mathrm{t}$ & Sig. \\
\cline { 2 - 4 } & $\mathrm{B}$ & Std. Error & Beta & & \\
\hline (Constant) & 11.648 & 11.429 & & 1.019 & .310 \\
VIEWS & .002 & .003 & .038 & .527 & .599 \\
REVIEW & 2.329 & .231 & .733 & 10.065 & .000 \\
REPUTATION & .000 & .000 & .053 & .829 & .409 \\
GOLD_MERC & 1.367 & 11.850 & .007 & .115 & .908 \\
\hline
\end{tabular}

a. Dependent Variable: SALES

Sumber : Data Penelitian, 2019

Hasil dari pengujian hipotesis 1 memiliki nilai sebesar 0,599 dimana nilai tersebut berada diatas batas alpha 0,05 sehingga hipotesis 1 ditolak. Hasil tersebut menyatakan bahwa viewer produk tidak memiliki dampak yang signifikan terhadap penjualan barang. Kondisi tersebut terjadi karena produk yang dilihat oleh banyak pelanggan belum tentu penjualannya tinggi. Seringkali pelanggan hanya melihat produk sekilas dengan beberapa pertimbangan seperti kualitas produk dan harga kemudian mencari produk lain untuk dibeli. Kotha, Rajgopal, Venkatachalam dan April, (2014) mengatakan bahwa barang yang 
dicantumkan dalam toko online dengan viewer yang tinggi tidak memiliki sales yang tinggi karena faktor pertimbangan harga produk dengan toko lain.

Hasil pengujian hipotesis 2 memiliki nilai sebesar 0,000 dimana nilai tersebut berada di bawah batas alpha 0,05 sehingga hipotesis kedua dapat diterima. Hasil tersebut menyatakan bahwa ulasan produk berpengaruh secara signifikan terhadap tingkat penjualan. Ulasan produk dari pelanggan sebelumnya membuat pelanggan yang lain percaya dengan kualitas produk yang ia beli sehingga tingkat kemungkinan pembeli untuk mengambil poduk tersebut meningkat. McKnight dan Chervany (2001) menyatakan bahwa kepercayaan pelanggan sangatlah penting dan dapat ditingkatkan dengan kepercayaan pelanggan lain melalui komentar dan ulasan. Masyarakat lebih memilih produk yang memilih jumlah ulasan banyak karena kualitas produk dan reliabilitas penjual lebih akurat dilihat dari sisi pelanggan lain daripada keterangan yang diberikan oleh penjual (Jaikumar, 2019).

Hasil pengujian hipotesis 3 memiliki nilai sebesar 0,409, nilai tersebut berada diatas batas alpha 0,05 sehingga hipotesis ketiga ditolak. Hasil tersebut menyatakan bahwa reputasi toko tidak berpengaruh dengan tingkat penjualan produk. Kondisi tersebut terjadi karena reputasi di toko online tidak terlalu jelas. Reputasi toko online hanya direpresentasikan melalui tingkat bintang yang ia miliki. Huang \& Benyoucef (2013) menyatakan bahwa selama toko tersebut berada dalam marketplace, yang terpenting adalah harga dan ulasan karena kepercayaan konsumen sudah berada di tangan marketplace itu sendiri.

Hasil pengujian hipotesis 4 memiliki nilai sebesar 0.908 dimana nilai tersebut berada diatas batas alpha sebesar 0,05 sehingga hipotesis 4 ditolak. Hasil tersebut membuktikan bahwa status gold merchant dalam tokopedia tidak berpengaruh terhadap tingkat penjualan produk. Gold merchant sendiri merupakan fitur status berbayar tambahan dari marketplace sehingga kepercayaan pelanggan untuk membeli produk masih dipengaruhi oleh beberapa faktor lainnya seperti harga, kualitas, dan ulasan dari pelanggan lain. Fitur toko berbayar kurang menarik kepercayaan pelanggan karena dapat diraih dengan membayar sejumlah uang, berbeda dengan jumlah ulasan yang dibuat berdasarkan pengalaman dari pelanggan lain. Pelanggan lebih percaya terhadap pengalaman pelanggan lain daripada status toko berbayar yang didapat dengan membayarkan sejumlah uang kepada marketplace.

\section{SIMPULAN}

Penelitian ini memperkaya bukti empiris bahwa ulasan pelanggan merupakan faktor yang paling penting dibandingkan dengan jumlah pengunjung produk, reputasi toko, dan gold badge dalam mempengaruhi tingkat penjualan marketplace. Penelitian ini dilakukan karena sebagian besar penelitian yang telah ada lebih fokus terhadap dampak dari sistem rekomendasi seperti iklan berbayar pada marketplace (Ou, 2011). Seringkali pelanggan mempertimbangkan faktor lain seperti ulasan untuk meyakinkan kualitas produk yang akan dibeli berdasarkan pengalaman pelanggan lain. Produk dengan kondisi "harga tinggi dan jumlah ulasan tinggi" lebih dipercaya masyarakat daripada produk dengan "harga rendah dan jumlah ulasan rendah (Jaikumar, 2019). Ulasan dinilai sangat berpengaruh karena dalam marketplace pelanggan tidak dapat melihat kualitas 
barang secara langsung sehingga lebih mempercayai pendapat dari pelanggan lain yang telah membeli produk. Ulasan produk bermanfaat untuk penjual karena dapat menentukan bahwa barang yang dibeli sesuai dengan keterangan yang diberikan penjual. Ulasan juga dapat memberikan nilai tambah lain bagi penjual ketika dalam ulasan tersebut disebutkan beberapa hal yang menambah reputasi penjual seperti kata-kata "penjual ramah", "barang dikirimkan dengan cepat", atau "respon penjual sangat cepat".

Penelitian ini menggunakan Tokopedia sebagi subjek penelitian dikarenakan perusahaan tersebut merupakan perusahaan marketplace yang pertama berdiri di Indonesia dan dianggap sudah matang dan stabil untuk menerapkan sistem rekomendasi secara online. Hasil penelitian menunjukkan bahwa viewer, reputasi toko, dan gold badge tidak berpengaruh terhadap penjualan. Hal ini disebabkan karena masih banyak faktor lain yang mempengaruhi pelanggan untuk membeli produk yang dijajakan pada toko tersebut. Sebaliknya, ulasan produk yang diberikan oleh pelanggan lain sangat berpengaruh terhadap tingkat penjualan. Hal tersebut dapat terjadi karena ulasan dari pelanggan sebelumnya dapat meningkatkan kepercayaan pelanggan lain terhadap kualitas produk yang akan dibeli.

\section{REFERENSI}

Abdullah, R. (2015). Pembelajaran Saintifik untuk Implementasi Kurikulum 2013. Jakarta: Bumi Aksara.

Adomavicius, G., \& Tuzhilin, A. (2005). Toward the next generation of recommender systems: A survey of the state-of-the-art and possible extensions. IEEE Transactions on Knowledge and Data Engineering, 17(6), 734749.

https://doi.org/10.1109/TKDE.2005.99

Alba, J., Lynch, J., Weitz, B., Janiszewski, C., Lutz, R., Sawyer, A., \& Wood, S. (1997). Interactive Home Shopping: Consumer, Retailer, and Manufacturer Incentives to Participate in Electronic Marketplaces. Journal of Marketing, 61(3), 38. https://doi.org/10.2307/1251788

Ansari, A., Essegaier, S., \& Kohli, R. (2000). Internet Recommendation Systems. Journal of Marketing Research, 37(3), 363-375. https://doi.org/10.1509/jmkr.37.3.363.18779

Arikunto, S. (2010). Prosedur Penelitian: Suatu Pendekatan Praktik. Jakarta: Rineka Cipta.

Caves, R. E., \& Greene, D. P. (1996). Brands' quality levels, prices, and advertising outlays: empirical evidence on signals and information costs. International Journal of Industrial Organization, 14(1), 29-52.

Chevalier, J. A., \& Mayzlin, D. (2006). The effect of word of mouth on sales: Online book reviews. Journal of Marketing Research, 43(3), 345-354.

Creyer, E. H. (1997). The influence of firm behavior on purchase intention: do consumers really care about business ethics? Journal of Consumer Marketing, 14(6), 421-432.

https:/ / doi.org/10.1108/07363769710185999

Dellarocas, C. (2003). The digitization of word of mouth: Promise and challenges 
of online feedback mechanisms. Management Science, 49(10), 1407-1424.

Eliashberg, J., \& Shugan, S. M. (1997). Film critics: Influencers or predictors? Journal of Marketing, 61(2), 68-78.

Grange, C., \& Benbasat, I. (2010). Online social shopping: The functions and symbols of design artifacts. Proceedings of the Annual Hawaii International Conference on System Sciences, 1-10.

https://doi.org/10.1109/HICSS.2010.293

Huang, Z., \& Benyoucef, M. (2013). From E-Commerce to social commerce: A close look at design features. Electronic Commerce Research and Applications, 12(4), 246-259.

https://doi.org/10.1016/j.elerap.2012.12.003

Jaikumar, S. (2019). How do consumers choose sellers in E-marketplaces?: The role of display price and sellers' review volume. Journal of Advertising Research, 59(2), 232-241.

https://doi.org/10.2501/JAR-2018-028

Keeney, R. L. (1999). The Value of Internet Commerce to the Customer. Management Science, 45(4), 533-542. https://doi.org/10.1287/mnsc.45.4.533

Kotha, S., Rajgopal, S., Venkatachalam, M., The, S., \& April, N. S. (2014). The role of online buying experience as a competitive advantage: Evidence from third-party ratings for e-commerce firms. The Journal of Business, 77(April 2004).

Luciana, A. (2017). Cerita Bos Tokopedia 2 Hari Kesulitan Rekrut Pegawai di Job Fair. Retrieved June 4, 2018, from https:/ / bisnis.tempo.co/read/1060782/cerita-bos-tokopedia-2-harikesulitan-rekrut-pegawai-di-job-fair

Mahadevan, B., \& Series, R. (2000). Business Models for Internet-Based E-Commerce: 42(4).

McKnight, D. H., \& Chervany, N. L. (2001). What trust means in E-Commerce customer relationships: An interdisciplinary conceptual typology. International Journal of Electronic Commerce, 6(2), 35-59. https:// doi.org/10.1080/10864415.2001.11044235

Nelson, P. (1970). Information and consumer behavior. Journal of Political Economy, 78(2), 311-329.

Nelson, P. (1974). Advertising as information. Journal of Political Economy, 82(4), 729-754.

$\mathrm{Ou}$, C. (2011). Nurturing sales entrepreneurship in consumer-to-consumer marketplaces. International Conference on Information Systems 2011, ICIS 2011, Vol. 5, pp. 3685-3694. Retrieved from https://www.scopus.com/inward/ record.uri?partnerID=HzOxMe3b\&scp= 84884653812\&origin=inward

Palmer, J. W. (2002). Web site usability, design, and performance metrics. Information Systems Research, 13(2), 151-167. https://doi.org/10.1287/isre.13.2.151.88

Pathak, B. (2014). Empirical analysis of the impact of recommender systems on sales. Journal of Management Information System, 27(2), 159-188.

Reinstein, D. A., \& Snyder, C. M. (2005). The influence of expert reviews on 
consumer demand for experience goods: A case study of movie critics. The Journal of Industrial Economics, 53(1), 27-51.

Schafer, J. Ben, Konstan, J. A., \& Riedl, J. (2001). E-Commerce Recommendation Applications. Applications of Data Mining to Electronic Commerce, 115-153. https://doi.org/10.1007/978-1-4615-1627-9_6

Spink, A. (2002). From E-Sex to E-Commerce: Web Search Changes. (March), 107109.

Walters, C. G. (1974). Consumer behavior: Theory and practice. McGraw-Hill/Irwin.

Zheng, W., \& Jin, L. (2016). A Consumer Decision-Making Model in MCommerce: In Information Resources Management Journal (Vol. 29). https://doi.org/10.4018/IRMJ.2016040103 